\title{
A Descriptive Study for the Impacts of Using Social Media on the Studies of University Students in Pakistan (A Literature Review.)
}

\author{
Dr. Sadaf Mustafa, (Assistant Professor) \\ Department of Commerce, University of Karachi, Pakistan
}

Doi:10.19044/esj.2018.v14n20p18 $\quad$ URL:http://dx.doi.org/10.19044/esj.2018.v14n20p18

\begin{abstract}
This research paper deals with the influence and contribution of Social Media for the studies of students in universities of Pakistan. Detail review of literature is adopted as methodology of this paper. The main objective of this study is to highlight the pros and cons of using social media by the students and emphasize on the positive usages. Mixed results are found while analyses were made on the basis of literature reviewed. It is observed that the use of social media and specifically social networking websites does not always have negative impacts. There are also some positive insights those are detailed in the paper under study. If correctly analyzed and appropriate strategies are formulated and implemented for the use of social media; it will certainly bring improvements in the knowledge and study patterns of university students. It is observed that social networks are also being used by the research students. Therefore, this paper will also help support in the field of research.
\end{abstract}

Keywords: Social Media, University Students, Pakistan

\section{Introduction}

Social Media is the form of communication made electronically through websites for sharing messages, idea information and other material. Social Networking, forums, social bookmarking and micro blogging are some of the forms of social media. Face book, Twitter, Wikipedia and LinkedIn are considered the prominent instances of social media. It is basically an electronic source of interaction and conversation.

Appended below is the briefing of some forms included in the Social Media:

\section{Social Networking}

A social network is a network or online service through which individuals may get connected with each other. 
Social networking is the use of social media based on internet to get connected with family, friends, classmates, clientele etc. It may be used for social as well as for business purposes through various sites.

\section{Forums}

A Forum is a website or a section of website where the public discussion on some specific topics are made through submitting and reading messages.

\section{Social bookmarking}

Social bookmarking is an online service that permits users to make additions, edition, annotation and sharing book marks of web documents. An important feature of social bookmarking is tagging where these book marks may be organized by users. Thus, favorite pages of users may be organized as per their priorities and future usage.

\section{Micro blogging}

Micro blogging is the online posting of brief messages. Most common of the websites supporting in micro blogging is twitter and face book.

Social media has gained popularity with the passage of time. It is being used by the individuals related to various areas for instance students, teachers, households, businessmen, salaried persons etc. However, the question of right or wrong continuously arises. Some portray the positive aspects of Social Media while others claim for the negative ones. Various studies have been conducted to analyze the actual impacts of these social websites and channels. Nevertheless, the research is still going on. Some have worked out on their influence on society while some on the students and academics. Somewhere, their impacts are also analyzed in the political and economic situation.

This paper tries to capture the impacts of social media on the studies of university students in Pakistan.

\section{Objective and Scope of Research}

The core objective of this study is to determine the role of Social Media in the studies of university students. It is intended to clarify the pros and cons of social media for the university students. This study will be helpful to design appropriate teaching strategies at university level to enhance the level of knowledge and understanding among the students.

\section{Review of Related Literature}

Social media is significantly contributing towards improvement in the standard of living as the same is supporting in the global access to the world markets and various services. This accessibility is not only enhancing the 
worldwide opportunities and connectivity but also resulting in some social issues specifically in the developing countries like Pakistan. Hence, related institutions of the country should assume responsibility of the necessary investigation and accountability. (Muqqadas Rehman, Khansa Irem and Muhammad Ilyas, 2014)

Using information technology in social media enhances its attractiveness in youth specifically in the students of universities. As per the case study conducted in the University of Sargodha, social media is helping out the students in education as well as approaching to cater the employment opportunities. However, some negative impacts of the same were also observed among the youth. (Asad Ali, Anam Iqbal and Kanwal Iqbal, 2016). Making the extraordinary use of the social media resulted in the adverse psychological and physical health. Though, these networks are supporting in the academics. However, the same is also resulting in the cyber crimes. These crimes are supposed to be controlled to an extent through awareness amongst the users. Moreover, an understanding of the distinction between the sites of social networking and social media will also help reduce such instances. (Hassan Khalid, 2017).

Social media performed a vital role to encourage alliances in order to develop an effective society across the world. However, problems were also observed to be faced in its usage. These problems that cause trouble during studies if relied upon include the availability of internet, electricity failures, the lack of privacy and the health issues. (Dr. Irshad Hussain, 2012). According to the statistical analysis of a study conducted on the school students of Abu Dhabi, mixed relationships were observed among learning from social networking, perceived performance, and the effect of social networking. Though, use of social networks contributes towards improvement in the reading skills. Nevertheless, its incorrect use may disturb the academics. (Masood Badri, Ali Al Nuaimi, Yang Guang and Asma Al Rashedi, 2017)

Probable attitude of teachers towards social media effects the academic achievements. While comparing teachers with respect to their attitudes towards social media, revealed the higher academic success of those having higher attitudes towards social media. Hence, significant positive correlation was found in between the same when tested statistically. (Dr. Murat Tezer, Ata Taşpolat, Ömer Sami Kaya, and Hamza Fatih Sapanca, 2017)

Use of social networking websites are supposed to distract students from their studies. Hence, the same should be discouraged on government as well as the parental level. This is required because no monitoring or control is there at the national level. (Waqas Tariq, Madiha Mehboob, M. Asfandyar Khan and FaseeUllah, 2012). Mahboob Rabbani, Anam Javeed, Muhammad Asif and Muhammad Ibrahim (2015) studied the impact of using social networks by students specifically with respect to age, gender and education. 
This study shows that most of the students in colleges use these networks for enjoyment.

Students are becoming addicted to the use of social websites. This addiction is being resulted in social harms as excessive use of anything does not bring benefits to the individuals and society as a whole. Therefore, balanced use of social media is suggested. (Rithika M and Sara Selvaraj, 2013)

Most of the post-graduate students make use of the social networks at large to gain knowledge and to remain connected with their social circle as well. However, some are reluctant in their use mainly because of the constraint of time and doubts about the privacy. (Dr Manzoor Hussain, Dr Fayaz Ahmad Loan and Gousia Yaseen, 2017). Attitudes of the students towards use of social networks vary with respect to the country they are residing in. (Heba Mohammad and Hatem Tamimi, 2017) concluded that these networks are being used by the students as support in their academics despite being time consuming. However, different modes are being preferred in different countries like facebook in Jorden and whatsapp by Saudi students. Abdulwahaab Alsaif (2016) argued that social behavior, academic performance, privacy and health related issues are the major factors in students' life that effected by social media. A slight variation was also observed in trends of using these websites with the passage of time.

Mohamed Haneefa K. and Sumitha E. (2011) studied the perception about social networking sites of the students in University of Calicut, Kerala. Findings of the study reveal that a considerable number of students in university visited such sites twice in every week in spite of having knowledge of the security and privacy issues therein and observed to show their true profile.

A study on the research skills of undergraduates in Nigeria shows that reliance of the students on inappropriate sources of information due to the use of some social networking sites may result in deteriorating research. However, they may have research ideas and enhance writing capabilities from the some. (Kanelechi C.K. Nwangwa, Ebun Yonlonfoun, Tope Omotere, 2014). Though, Social Media effects the students adversely, however, it may be productive if used appropriately. Hence, teachers should guide students towards the correct and productive use of social networking websites. (Osharive Peter, 2015). Facebook, Twitter, My Space, Skype, LinkedIn, and Ning are some sites those are famous amongst the youth. However, positives and negatives of these should be clear to them to avoid adverse impacts in case of excessive or incorrect use and to help them set their priorities accordingly. (Khurana N, 2015)

Anil Kumar and Rajinder Kumar (2013) made an attempt to analyse the use of social networks by research scholars and postgraduate students of 
Maharishi Dayanand University, India. Facebook was observed to be the most famous website by students and research scholars. It was revealed that university has blocked some sites that should not be the case as these sites are helpful for the research scholars to share their profile and students to remain connected with each other.

\section{Hypothesis}

H1: Social Media is making positive contribution in the studies of University students of Pakistan

H0: Social Media is making positive contribution in the studies of University students of Pakistan

\section{Research Methodology}

The study in hand is a descriptive one and is based on the analysis and results of the work executed earlier in the relevant area. This methodology is carried out through the study of literature related to the impacts of social networking websites on students. Hence, the same analyses the influence and contribution of social media in the students of universities in Pakistan.

\section{Conclusion}

Study under consideration is a descriptive one that is conducted and concluded on the basis of literature. Though mixed results were found for the positive and negative outcomes of using social media websites and channels. However, it is concluded that use of this technology is increasing all over the world and in developing countries including Pakistan. It has both its pros and cons and its use cannot be avoided to remain competitive and align with the requirements of changing scenarios. Nevertheless, the major responsibility lies on the teachers in universities how they educate their use to the students.

\section{$\underline{\text { Suggestions }}$}

In view of the above findings, it is suggested that first lecturers and professors should be educated through a comprehensive program country wide. Later on, these teachers should guide the students accordingly. It seems to be the possible and appropriate way through which negative usages of social media may be minimized and productive ones may be enhanced.

\section{$\underline{\text { Limitations }}$}

The above study is limited to the data collected, the time restraints and the resources required to proceed with the research procedure. 


\section{Identified Areas for Further Research}

Further research may be conducted on the stated topic by conducting a survey and having opinions of the students and teachers of universities in Pakistan.

\section{References:}

1. Ali, A., Iqbal, A., \& Iqbal, K. (2016). Effects of Social Media on Youth: A Case Study In University of Sargodha. International Journal of Advanced Research (IJAR), 4(11), 369-372. doi:10.21474/IJAR01/2093

2. Alsaif, A. (2016, April). Investigate The Impact of Social Media on Students. Cardiff Metropolitan University.

3. Badri, M., Al Nuaimi, A., Guang, Y., \& Al Rashedi, A. (2017). School performance, social networking effects, and learning of school children: Evidence of reciprocal relationships in $\mathrm{Abu}$ Dhabi. ELSEVIER, 1433-1444.

4. Haneefa K., M., \& E., S. (2011). Perception and Use of Social Networking Sites by the Students of Calicut University. DESIDOC Journal of Library \& Information Technology, 31(4), 295-301.

5. Hussain, D. I. (2012). A Study to Evaluate the Social Media Trends among University Students. International Educational Technology Conference IETC2012 (pp. 639 - 645). Elsevier 1TD.

6. Hussain, D. M., Loan, D. F., \& Yaseen, G. (2017). The Use Of Social Networking Sites (SNS) By The Post-Graduate Students. International Journal of Digital Library Services, 7(1).

7. Khalid, H. (2017). The Effects of Social Networks on Pakistani Students. Information Technology \& Software Engineering. doi:10.4172/2165-7866.1000203

8. Kumar, A., \& Kumar, R. (n.d.). Use of Social Networking Sites (SNSs): A study of Maharishi Dayanand University, Rohtak, India. Library Philosophy and Practice (e-journal).

9. M., R., \& Selvaraj, S. (2013). Impact of Social Media On Student's Academic Performance. International Journal of Logistics \& Supply Chain Management Perspectives, 2(4).

10. Mohammad, H., \& Tamimi, H. (2017). Students' Perception Of Using Social Networking Websites For Educational Purposes: Comparison Between Two Arab Universities. International Journal of Managing Information Technology (IJMIT), 9(2). doi:DOI : 10.5121/ijmit.2017.9202

11. N, K. (2015). The Impact of Social Networking Sites on the Youth. Journal of Mass Communication \& Journalism, 5(12). doi:10.4172/2165-7912.1000285 
12. Nwangwa, K. C., Yonlonfoun, E., \& Omotere, T. (2014). Undergraduates and Their Use of Social Media: Assessing Influence on Research Skills. Universal Journal of Educational Research, 2(6), 446-453. doi:10.13189/ ujer.2014.020602

13. Peter, O. (2015). Social Media And Academic Performance Of Students In University Of Lagos.

14. Rabbani, M., Javeed, A., Asif, M., \& Ibrahim, M. (2015). Impact of Social Networking Websites on Students learning. IISTE, 44.

15. Rehman, M., Irem, K., \& Ilyas, M. (2014). Social Media: A Prospective or a Dilemma The case of Pakistan. Inte rnational Journal of Management Research and Emerging Sciences, 4(1), 47-68.

16. Tariq, W., Mehboob, M., Khan, M. A., \& FaseeUllah. (2012). The Impact of Social Media and Social Networks on Education and Students of Pakistan. IJCSI International Journal of Computer Science Issues, 9(4).

17. Tezer, D. M., Taşpolat, A., Kaya, Ö. S., \& Sapanca, H. F. (2017). The Impact Of Using Social Media On Academic Achievement And Attitudes Of Prospective Teachers. (IJCRSEE) International Journal of Cognitive Research in Science, Engineering and Education, 5(2). 